\title{
Induction of apoptosis by the angucyclinone antibiotic chemomicin in human tumor cells
}

\author{
YONG LI*, NINGNING HAN*, NING GAO, RONG XU, CHENGHANG SUN, DIANDONG LI and QIYANG HE \\ Institute of Medicinal Biotechnology, Peking Union Medical College and \\ Chinese Academy of Medical Sciences, Beijing 100050, P.R. China
}

Received July 24, 2009; Accepted October 6, 2009

DOI: 10.3892/or_00000658

\begin{abstract}
Chemomicin (CHM), an angucyclinone antibiotic extracted from the fermentation broth of Nocardia Mediterranei subsp. Kanglensis 1747-64, shows immunosuppressive activity. However, whether it can inhibit growth of tumor cells remains elusive. In the present study, we show that CHM potently inhibited the proliferations of eight various types of human tumor cell lines and non-cross resistant to multidrugresistant cells. In contrast to action of doxorubicin, the generation of reactive oxygen species was observed as early as $30 \mathrm{~min}$ after addition of CHM and its process did not involve iron. The apoptotic cells with chromatin condensation and Annexin V staining markedly increased after the human hepatoma HepG2 was exposed to 1 , or $2 \mu \mathrm{g} / \mathrm{ml} \mathrm{CHM}$ for $24 \mathrm{~h}$. In the CHM-induced apoptosis, robust increment of p53 expression, activation of caspase- $3,-7,-8,-9$, cleavage of PARP and the phosphorylation of p38 and JNK, were detected by Western blot analysis. Further investigation revealed the disruption of mitochondrial membrane potential in the cells with CHM incubation for $4 \mathrm{~h}$. Taken together, the results demonstrated that potent proliferation inhibitory effect of CHM on tumor cells is due to activation of the apoptotic pathway.
\end{abstract}

\section{Introduction}

It is critical to develop new antitumor agents for challenging high rates of global cancer incidence (1). In addition to targeting new drugs, new types of antitumor antibiotics are also receiving keen attention. CHM (original name kanglemycin C, Fig. 1), an angucyclinone antibiotic, is isolated from the fermentation broth of Nocardia mediterranei subsp. kanglensis 1747-64 (2). It was preliminarily developed

Correspondence to: Dr Qiyang He or Dr Chenghang Sun, Institute of Medicinal Biotechnology, No. 1 Tiantan Xili, Beijing 100050 P.R. China

E-mail: gyh2000bj@yahoo.com.cn or chenghangsun@hotmail.com

*Contributed equally

Key words: chemomicin, angucyclinone antibiotic, doxorubicin, reactive oxygen species, apoptosis, human tumor cells as an immunosuppressive agent for revealing strong suppression of T- and B-lymphocyte proliferation (3). Similar activity of $\mathrm{CHM}$ has been reported in the mouse immune system to cyclosporine A $(4,5)$. However, whether $\mathrm{CHM}$ can inhibit the proliferation of tumor cells remains unknown.

Induction of apoptosis plays a very important role in chemotherapy. Accumulating evidences show that extrinsic and intrinsic apoptotic pathways are triggered by antitumor agents $(6,7)$. The extrinsic pathway is mediated by the engagement of death receptors on the cell membrane. The formation of death-induced signaling complex recruits caspase- 8 and promotes the cascade of procaspase activation that follows. The intrinsic pathway initiates the apoptotic cascades by the convergence of the signaling at mitochondria and then follows the alteration of mitochondrial membrane potential, the release of cytochrome $\mathrm{c}$ into the cytosol and activation of caspase cascade. Several kinds of kinases regulate apoptotic signaling pathways. Akt prevents apoptosis by phosphorylating proapoptotic proteins such as Bad, and caspase-9, and by activating transcriptional factors, such as forkhead box class O (FOXO)-1 and NF-кß $(8,9)$. MAPK-p38 and c-Jun N-terminal kinases (JNKs) can respond to stress and transmit the apoptotic signals $(10,11)$.

In this study, using anthracycline antibiotic doxorubicin (DOX) as a control drug, we provide the evidence that CHM potently inhibits the proliferations of tumor cells via activation of the apoptotic pathway.

\section{Materials and methods}

Reagents. CHM was extracted from the fermentation broth of Nocardia Mediterranei subsp. Kanglensis 1747-64 and purified according to the method reported previously (12). The purity was $>94 \%$ as examined by HPLC. It was prepared into a 20 $\mathrm{mg} / \mathrm{ml}$ solution with dimethyl sulfoxide (DMSO) and stored at $-20^{\circ} \mathrm{C}$ before use. DMSO, 3-(4, 5-dimethyl-2 thiazoyl) -2, 5diphenyl-2H-tetrazolium bromide (MTT), rhodamine 123, Hoechst 33342, RNase A, N-acetyl-L-cysteine (NAC), propidium iodide (PI), deferoxamine (DFO), DOX were purchased from Sigma-Aldrich Chemical Inc. (St. Louis, MO, USA). $\mathrm{H}_{2}$ DCFDA, RPMI-1640 medium, DMEM medium were obtained from Invitrogen (Carlsbad, CA, USA).

Cell lines and culture condition. Human hepatoma BEL-7402 and HepG2 cells, aryngocarcinoma KB cells, non-small lung 
cancer A549 cells, breast cancer MCF-7 cells, prostate carcinoma PC3 cells, gastric carcinoma BGC-823 cells, nasopharyngeal carcinoma $\mathrm{KB}$ and vincristine-resistant $\mathrm{KBV} / 200$ (a gift of Dr Gengtao Liu, Institute of Materia Media, Chinese Academy of Medical Sciences), were cultured in RPMI-1640 medium. Colon carcinoma HCT116 p53 wild-type and p53 knocked out cells, a kind gift of Dr Bert Vogelstein (Johns Hopkins University, Baltimore, USA), were cultured in DMEM medium. All the media were supplemented with $10 \%$ fetal bovine serum (Tianjin Haoyang Biotech Company, Tianjin, China), $2 \mathrm{mM}$ glutamine, 100 units $/ \mathrm{ml}$ penicillin and streptomycin, respectively. The cells were incubated at $37^{\circ} \mathrm{C}$ in humidified $5 \% \mathrm{CO}_{2}$.

Cell viability assay. MTT assay was used to assess cell viability. Cells at density of $4 \times 10^{3} /$ well were seeded in a 96-well plate for $24 \mathrm{~h}$ and then treated with CHM for $72 \mathrm{~h}$. The final concentration of DMSO in CHM-treated media was $<0.1 \%$. Then $10 \mu 15 \mathrm{mg} / \mathrm{ml}$ MTT was added to the medium and incubated for $2 \mathrm{~h}$ at $37^{\circ} \mathrm{C}$. After removing culture medium, $200 \mu \mathrm{l}$ DMSO was added to solubilize the blue formazan formed by viable cells. Plates were read using an ELISA plate reader at $570 \mathrm{~nm}$. The viability of untreated cells was set as $100 \%$ and viability in other groups was calculated by comparing the optical density reading with the control.

Cell cycle analysis. The cells were trypsinized and washed once with PBS and then fixed with cold $70 \%$ ethanol overnight. The fixed cells were washed twice with PBS and incubated with $100 \mu \mathrm{g} / \mathrm{ml}$ of RNase A at $37^{\circ} \mathrm{C}$ for $30 \mathrm{~min}$ and then stained in PBS containing $50 \mu \mathrm{g} / \mathrm{ml}$ PI for $30 \mathrm{~min}$. The fluorescent intensity was detected by BD FACSCalibur cytometer (BD Biosciences, CA, USA) and cell cycle distribution was assayed with ModFit LT software.

Observation of chromatin condensation. Cells ( $2 \times 10^{5}$ per well) were seeded in a 6-well plate for $24 \mathrm{~h}$ and treated with $\mathrm{CHM}$ for $24 \mathrm{~h}$. The suspended and adhered cells were collected and incubated with $2 \mu \mathrm{g} / \mathrm{ml}$ Hoechst 33342 at $37^{\circ} \mathrm{C}$ for $30 \mathrm{~min}$. Chromatin condensation was observed with a fluorescence microscopy (Nikon, Japan).

Detection of apoptotic cells by Annexin V/PI staining. The apoptotic cells were detected by an Apop Nexin ${ }^{\text {TM }}$ FITC apoptosis detection kit (Chemicon, CA, USA) according to the manufacturer's instruction. Briefly, suspended and adherent cells were pooled, washed twice with ice-cold PBS. Cell suspension $(0.2 \mathrm{ml})$ was incubated with $3 \mu \mathrm{l}$ of FITC-labeled Annexin V and $2 \mu \mathrm{l}$ of PI at room temperature in the dark and then assayed within $1 \mathrm{~h}$ by a BD FACSCalibur cytometer.

Western blot analysis. After CHM treatment at indicated times, cells were harvested and lysed in the buffer containing $25 \mathrm{mM}$ Tris- $\mathrm{HCl}, \mathrm{pH}$ 7.5, $150 \mathrm{mM} \mathrm{NaCl}, 2$ mM EDTA, $10 \%$ glycerol, $10 \mathrm{mM}$ glycerophosphate, $5 \mathrm{mM}$ sodium pyrophoshate, $5 \mathrm{mM}$ $\mathrm{NaF}, 1 \mathrm{mM} \mathrm{Na} \mathrm{VO}_{4}, 0.5 \%$ Triton X-100, freshly added with $1 \mathrm{mM}$ PMSF, $2 \mu \mathrm{g} / \mathrm{ml}$ aprotinin and $2 \mu \mathrm{g} / \mathrm{ml}$ leupeptin. Protein $(40 \mu \mathrm{g})$ was loaded for SDS-PAGE and transferred to a PVDF membrane and probed by corresponding antibodies. Antibodies against poly (ADP-ribose) polymerase (PARP,

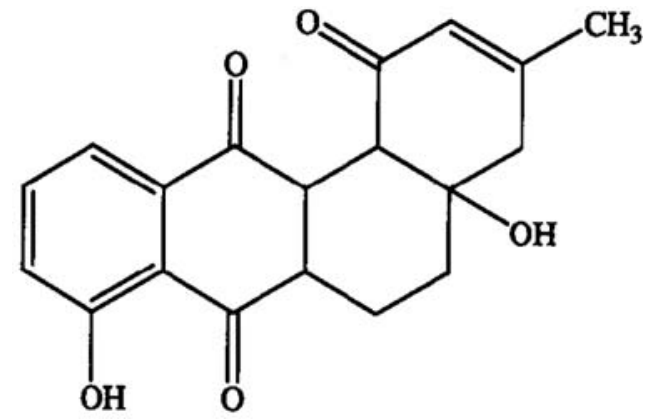

Figure 1. The chemical structure of CHM.

9542), cleaved caspase -7 (9491), cleaved caspase-9 (9505), caspase-8 (9746), Akt (9272), phospho-Akt (Ser473, 9271), JNK (9258), phospho-JNK (Thr183/Tyr185, 9251), p38 (9212), phospho-p38 (Thr180/Tyr182, 9211), were obtained from Cell Signaling Technology (Beverly, MA, USA). Antip53 (sc-126) and anti-Actin antibodies (sc-1616) were from Santa Cruz Biotechnology (Santa Cruz, CA, USA). The protein signals were detected by the enhanced chemiluminescence reaction system according to the manufacturer's recommendation (Amersham Biosciences, Indianapolis, USA).

Mitochondrial membrane potential ( $\triangle \Psi m$ ) and ROS assays. Cells at $2 \times 10^{5}$ per well were seeded in a 6 -well plate for $24 \mathrm{~h}$ and treated with different concentrations of CHM. The cells for the detection of $\Delta \Psi \mathrm{m}$ were incubated with $0.5 \mathrm{mM}$ rhodamine 123 for $30 \mathrm{~min}$. For ROS assay, the cells were incubated with $10 \mu \mathrm{M} \mathrm{H}_{2}$ DCFDA at $37^{\circ} \mathrm{C}$ for $1 \mathrm{~h}$ in the dark. The intracellular fluorescence intensity was measured with a BD FACSCalibur cytometer.

Statistical analysis. Each experiment was performed two or three times. Data were plotted as means \pm standard deviation. Student's t-test was used for comparisons. Differences were considered significant at $\mathrm{P}<0.05$.

\section{Results}

Potent inhibition of CHM toward human solid tumor cells. MTT assay was used to examine the cell proliferation inhibitory effect of CHM on various types of tumor cell lines. The $\mathrm{IC}_{50}$ values of $\mathrm{CHM}$ toward eight different kinds of tumor cells are summarized in Table I. Interestingly, no cross resistance to $\mathrm{CHM}$ were found on doxorubicin-resistant $\mathrm{MCF}-7 / \mathrm{DOX}$ or vincristine-resistant $\mathrm{KB}$ cells, indicating that $\mathrm{CHM}$ can be used to overcome multidrug resistance. Similar sensitivity to CHM of the p53 wide-type and p53 knockouttype of HCT116 cells was observed, suggesting that action of $\mathrm{CHM}$ is p53-independent. We chose hepatoma HepG2 cells for the following experiments.

Partial arrest of cells at G2/M phase without involvement of iron after incubation with CHM. Many cytotoxic antitumor agents interfere the running of cell cycle. The cell cycle distribution was assayed by flow cytometry after HepG2 cells were treated with CHM. DOX, an antitumor agent with similar chemical structure as CHM, was used as a positive control. 
Table I. Cytotoxicities of CHM on human solid tumor cell lines. ${ }^{a}$

\begin{tabular}{ll} 
Cell lines & $\mathrm{IC}_{50}(\mu \mathrm{g} / \mathrm{ml})$ \\
\hline Breast cancer MCF-7 cells & $0.52 \pm 0.14$ \\
Breast cancer MCF-7/DOX cells & $0.55 \pm 0.12$ \\
Nasopharyngeal carcinoma KB cells & $0.47 \pm 0.14$ \\
Nasopharyngeal carcinoma KBV/200 cells & $0.54 \pm 0.11$ \\
Colon carcinoma HCT116 cell p53 wt cells & $0.85 \pm 0.09$ \\
Colon carcinoma HCT116 cell p53 ko cells & $0.74 \pm 0.12$ \\
Prostate carcinoma PC3 cells & $0.67 \pm 0.13$ \\
Lung carcinoma A549 cells & $0.50 \pm 0.11$ \\
Stomach carcinoma BGC-823 cells & $0.42 \pm 0.11$ \\
Hepatoma BEL-7402 cells & $0.57 \pm 0.10$ \\
Hepatoma HepG2 cells & $0.48 \pm 0.11$ \\
Ovarian carcinoma SKOV-3 cells & $0.89 \pm 0.07$ \\
\hline
\end{tabular}

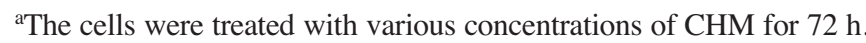
Cell survival was determined by MTT assay. The data represent the mean \pm SD from three independent experiments.
As shown in Fig. 2, only $10 \%$ of the cells at $\mathrm{G}_{2} / \mathrm{M}$ phase increased following exposure to $0.5 \mu \mathrm{g} / \mathrm{ml} \mathrm{CHM}$ for $24 \mathrm{~h}$ and the process was not affected by exposure to $20 \mu \mathrm{M}$ DFO, a chelator of iron, in comparison with untreated cells. By contrast, the arrest of cells at $\mathrm{G}_{2} / \mathrm{M}$ phase with $50 \mathrm{nM}$ DOX treatment was partly reversed after addition of $20 \mu \mathrm{M}$ DFO (Fig. 2d).

Generation of ROS triggered by CHM treatment. In order to compare the difference of action between CHM and DOX, the specific fluorescence dye $\mathrm{H}_{2}$ DCFDA was used to monitor the generation of ROS. In contrast to slight ROS generation with $1 \mu \mathrm{M}$ DOX treatment, it was detected as early as $30 \mathrm{~min}$ following the HepG2 cell exposure to the concentrations of $1,2,5 \mu \mathrm{g} / \mathrm{ml} \mathrm{CHM}$, respectively (Fig. 3). The generation of ROS is concentration- and time-dependent. In order to confirm the specificity of ROS generation, the CHM- treated HepG2 cells were co-incubated with $5 \mathrm{mM}$ NAC, a scavenger of ROS. The generation of ROS was abrogated by NAC (data not shown).

Induction of apoptosis by CHM in tumor cells. To identify the mechanism by which CHM inhibits the proliferation of tumor cells, we assayed the characteristics of CHM-induced
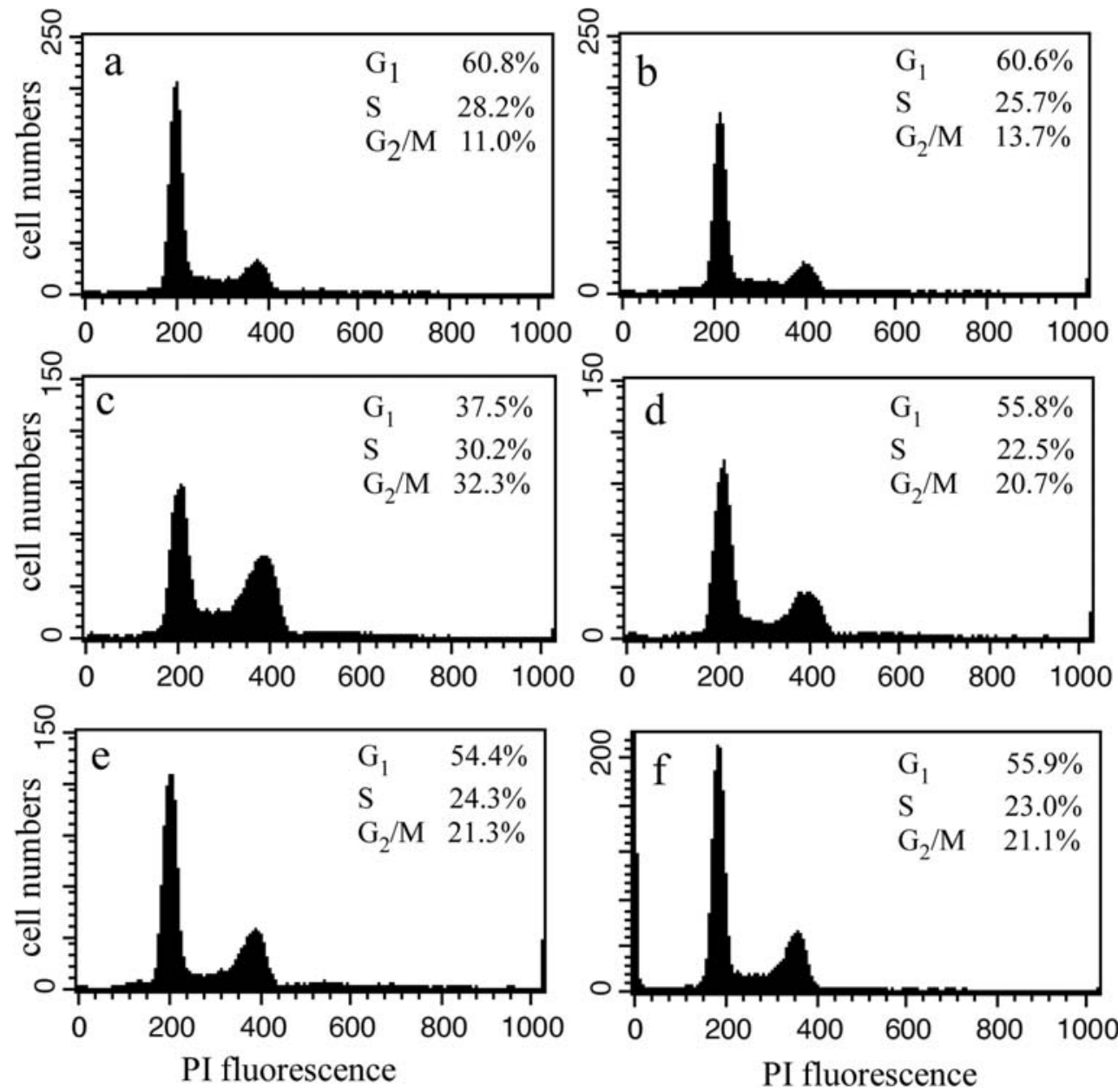

Figure 2. Partial arrest of cells at $\mathrm{G}_{2} / \mathrm{M}$ phase without involvement of iron after incubation with CHM. The HepG2 cells were treated with the drugs for 24 h: (a) control; (b) $20 \mu \mathrm{M} \mathrm{DFO;} \mathrm{(c)} 50 \mathrm{nM} \mathrm{DOX;} \mathrm{(d)} 50 \mathrm{nM} \mathrm{DOX}+20 \mu \mathrm{M} \mathrm{DFO}$; (e) $0.5 \mu \mathrm{g} / \mathrm{ml} \mathrm{CHM}$; (f) $0.5 \mu \mathrm{g} / \mathrm{ml} \mathrm{CHM}+20 \mu \mathrm{M} \mathrm{DFO}$. The fixed cells were stained with PI and detected by flow cytometry. The results are representative of two independent experiments. 

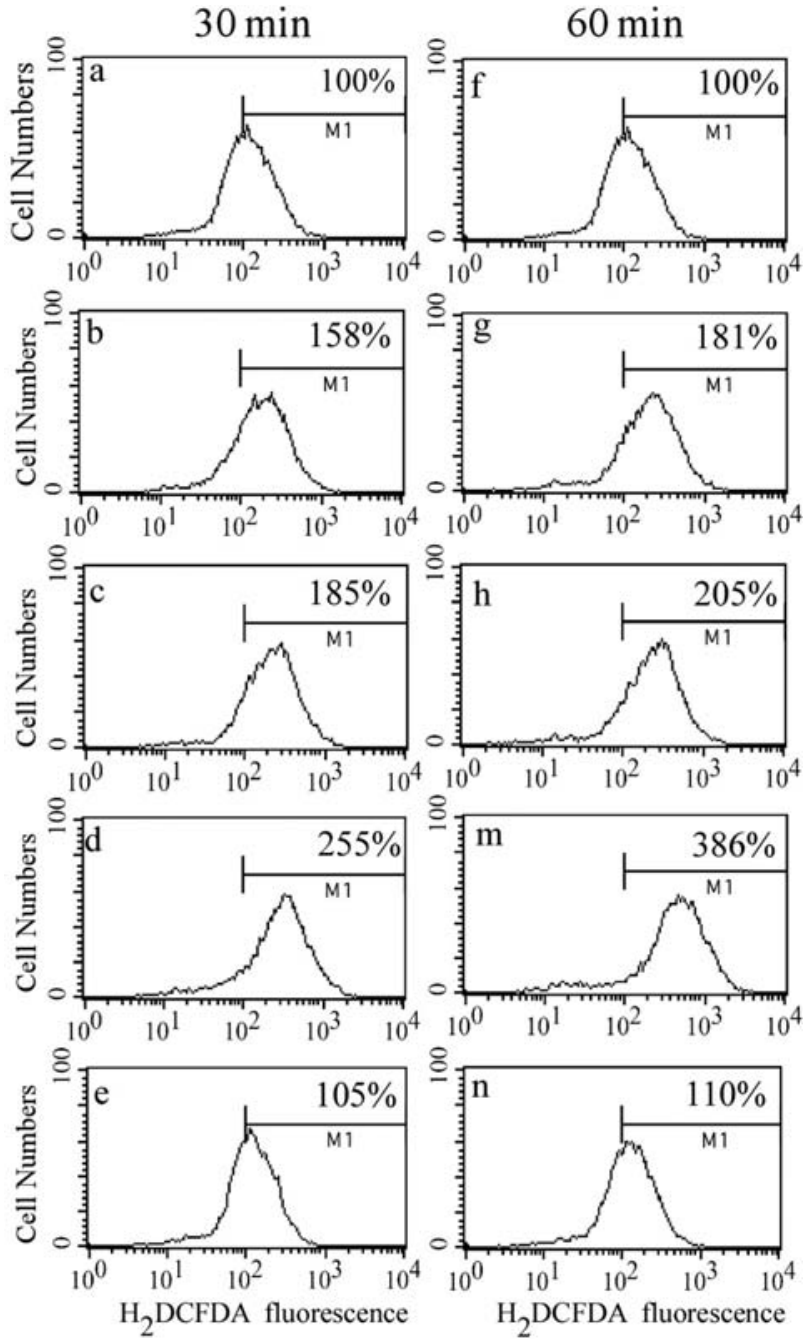

Figure 3. Generation of ROS triggered by CHM treatment. The HepG2 cells were incubated with 1 (b and $\mathrm{g}$ ), 2 (c and h), 5 ( $\mathrm{d}$ and $\mathrm{m}) \mu \mathrm{g} / \mathrm{ml} \mathrm{CHM}$ and $1 \mu \mathrm{M}$ DOX (e and $\mathrm{n}$ ) for 30 and $60 \mathrm{~min}$, respectively. After staining with $10 \mu \mathrm{M} \mathrm{H}_{2}$ DCFDA in fresh medium for $1 \mathrm{~h}$, the cells were assayed with FACSCalibur cytometer. Figures a and f represent untreated cells. The results are representative of three separate experiments.

apoptosis. The chromatin condensation, an apoptotic marker, was observed in the HepG2 cells exposed to 1 , or $2 \mu \mathrm{g} / \mathrm{ml}$ CHM for $24 \mathrm{~h}$ (Fig. 4A). The apoptotic cells were also detected by flow cytometry with Annexin V staining. As shown in Fig. 4B, 49.3 and $71.2 \%$ of cells revealed Annexin V positively staining following incubation with 1 , or $2 \mu \mathrm{g} / \mathrm{ml} \mathrm{CHM} \mathrm{for}$ $24 \mathrm{~h}$. These data indicate that CHM can induce typical apoptotic features in the tumor cells.

Disruption of mitochondrial membrane potential ( $\Delta \Psi m)$ in CHM-induced apoptosis. Next we explored an early apoptotic event such as the alteration of mitochondrial membrane potential in the process of CHM-induced apoptosis. The rhodamine 123 , a fluorescent dye sensitive to changes of mitochondrial membrane potential, was used for flow cytometry assay in the HepG2 cells. As demonstrated in Fig. 5, the values of $\Delta \Psi \mathrm{m}$ decreased to 78,62 and $52 \%$ of untreated cell level at concentrations of 1,2 and $5 \mu \mathrm{g} / \mathrm{ml} \mathrm{CHM}$ incubation for $4 \mathrm{~h}$, respectively, indicating that $\mathrm{CHM}$-induced apoptosis involves in the mitochondrial apoptotic pathway.

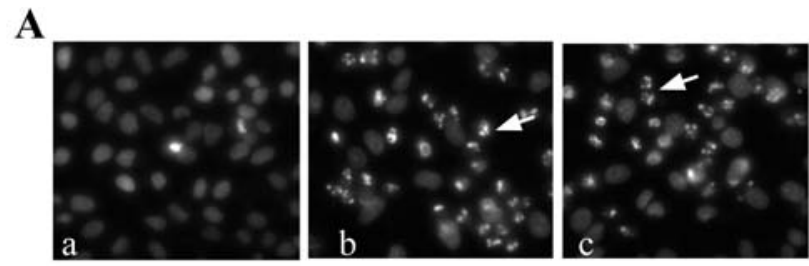

B
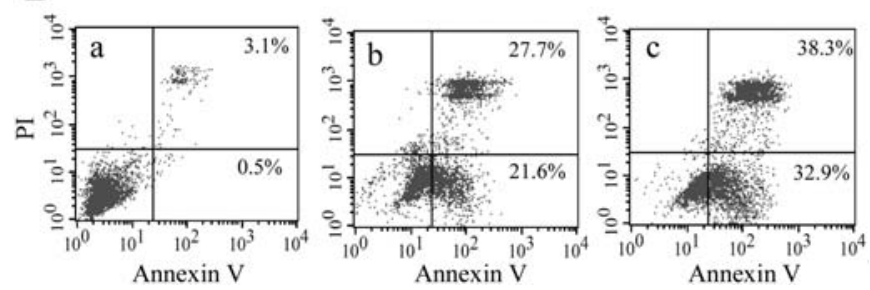

Figure 4. Induction of apoptosis by CHM treatment in tumor cells. (A) Chromatin condensation assessed by fluorescence microscopy with Hoechst 33342 staining. (Aa) Untreated cells, (Ab) the cells treated with $1 \mu \mathrm{g} / \mathrm{ml}$ $\mathrm{CHM}$ for $24 \mathrm{~h}$, (Ac) the cells treated with $2 \mu \mathrm{g} / \mathrm{ml} \mathrm{CHM}$ for $24 \mathrm{~h}$. (B) Apoptotic cells stained with Annexin V and detected by flow cytometry. (Ba) Untreated cells, $(\mathrm{Bb})$ the cells treated with $1 \mu \mathrm{g} / \mathrm{ml} \mathrm{CHM}$ for $24 \mathrm{~h},(\mathrm{Bc})$ the cells treated with $2 \mu \mathrm{g} / \mathrm{ml} \mathrm{CHM}$ for $24 \mathrm{~h}$. The results are representative of three separate experiments.

Activation of caspase pathways in CHM-induced apoptosis. Apoptosis is tightly controlled by multi-steps, orderly participated by caspases such as initiator caspase-2, -8, -9, -10 and executioner caspase-3, $-6,-7$ and then cleavage of PARP by the activated caspase- 3 . To determine the activation of caspase cascade in CHM-induced apoptosis, HepG2 cells were exposed to different concentrations of CHM for $24 \mathrm{~h}$ and then assayed by Western blot analysis. The results showed that the cleavage of PARP to a $89 \mathrm{kDa}$ fragment and emergence of cleaved caspase- $9,-3,-7$ were observed, in a concentrationdependent way (Fig. 6A). Cleaved caspase-8, indictor of activation of extrinsic apoptotic pathway, was also detected in CHM-induced apoptosis. These data suggest that CHMinduced apoptosis in tumor cells is due to activation of the caspase cascade.

Signaling pathway triggered by CHM treatment. To decipher the signaling pathway of apoptosis induced by CHM, phosphorylations of Akt, p38, and JNK were detected after the HepG 2 cells were treated with $1 \mu \mathrm{g} / \mathrm{ml} \mathrm{CHM}$ for the indicted times (Fig. 6B). The expression of p53 increased as early as $2 \mathrm{~h}$ and decreased at $12 \mathrm{~h}$ after adding CHM, suggesting that activation of p53 may be involved in the CHM-induced apoptosis. The phosphorylation level of Akt increased at 2-8 $\mathrm{h}$ and then decreased. It is difficult to explain why the phosphorylations of p38 and JNK were elevated at 12, $24 \mathrm{~h}$ as apoptosis occurred. The total levels of Akt, p38, and JNK were not influenced by CHM treatment.

\section{Discussion}

In this study, we provided evidence that the cytotoxic action of CHM toward tumor cells is due to activation of apoptotic pathways, as demonstrated by the appearance of chromatin condensation, activation of caspases and cleavage of PARP. To our knowledge, this is the first study reporting that 

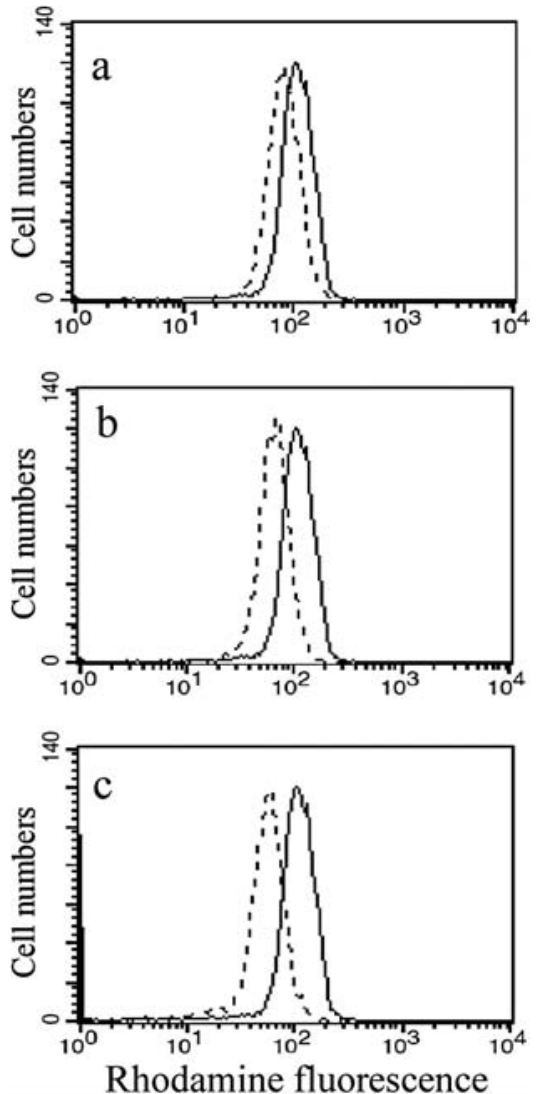

Figure 5. Reduction of mitochondria membrane potential $(\Delta \Psi \mathrm{m})$ in CHMinduced apoptosis. HepG2 cells were stained with fluorescence dye rhodamine 123 for 30 min after $4 \mathrm{~h}$ incubation with CHM and then analyzed by flow cytometry. Solid lines show untreated cells and dash lines represent CHMtreated cells at the concentrations of 1 (a), 2 (b) and $5 \mu \mathrm{g} / \mathrm{ml}$ (c), respectively. The results are representative of two separate experiments.

angucyclinone antibiotics trigger activation of apoptotic pathways in tumor cells though many of this antibiotic group revealed antitumor activities (12-15). The generation of ROS and disruption of mitochrondrial membrane potentials in CHM treatment lead to activation of intrinsic apoptotic pathway, consistent with the study that the action of angucycline antibiotic landomycin $\mathrm{E}$ induces $\mathrm{KB}-3-1$ cells to apoptosis (16). In addition, we also detected the cleaved caspase- 8 fragments (Fig. 6A), indicating that CHM-induced apoptosis may involve in extrinsic apoptotic pathway. The feature is similar to action of DOX as it can activate the extrinsic pathway (17).

Although signaling pathway triggered by CHM treatment revealed the activation of JNK and p38 kinases, the time of their phosphorylations occurred late when high rate of apoptosis appeared according to the PARP cleavage. It differs from other antitumor agents. It has been reported that paclitaxel-induced apoptosis activated the JNK phosphorylation at $4 \mathrm{~h}$ after exposure to paclitaxel, though the cleaved caspase-9 appeared at $24 \mathrm{~h}$ (18). In DOX-induced apoptosis in breast cancer cells, phophorylations of JNK and p38 were observed following $10 \mu \mathrm{g} / \mathrm{ml}$ DOX for $1 \mathrm{~h}$, but Annexin V-binding cells were $\sim 50 \%$ at $24 \mathrm{~h}$ (19). This means that activation of JNK and p38 usually transmits apoptotic signal to activation of caspase cascade. The role of ROS in
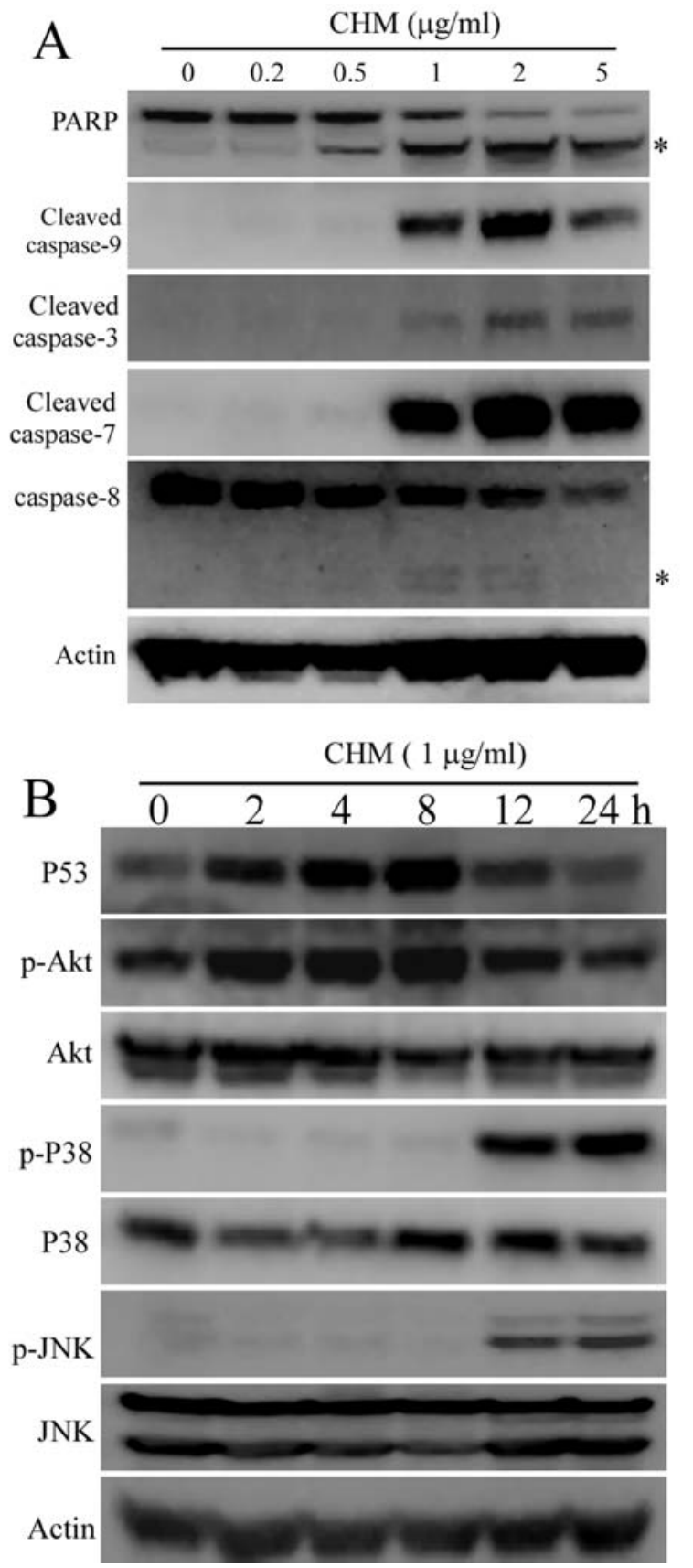

Figure 6. (A) Activation of caspase cascade in CHM-induced apoptosis. The HepG2 cells were treated with different concentrations of CHM for $24 \mathrm{~h}$ and protein lysates were analyzed by Western blot analysis. Asterisk (*) indicates the cleaved fragments. The results are representative of three separate experiments. (B) Signaling pathway in CHM-induced apoptosis. HepG2 cells were treated with $1 \mu \mathrm{g} / \mathrm{ml} \mathrm{CHM}$ for the indicated times. Protein lysates were analyzed by Western blot analysis. The results are representative of two separate experiments.

apoptosis should be taken into account. There is accumulating evidence that ROS generation is an intermediated signal to initiate the intrinsic pathway by several antitumor agent treatments, such as paclitaxel, cisplatin, arsenite and DOX (20-23). However, ROS generation rapidly triggered by CHM treatment may directly activate the intrinsic apoptotic pathway as it has been reported that DOX or its metabolites directly affected mitochondria and promote apoptosis $(24,25)$. If this occurs, one can easily understand the late phosphorylation of JNK and p38 after CHM treatment. 
According to the definition of Rohr and Thiericke (26), angucycline/angucyclinone antibiotics possess a basic chemical structure of tetrancyclic benz[a]anthracene frame, which is assembled in an angular manner. It distinguishes from anthracyclines having linearly assembled tetracyclic ring frames. As to classification of angucycline and angucyclinone, the former includes those with hydrolysable sugar moieties, while the latter refers to a sugarless compound. There are ample reports that these antibiotics have various biological actions, including antitumor activity (2732). Landomycins belong to angucycline antibiotics with sugar moieties and have promising antitumor activities in vitro and in vivo (33). No arrest of the cell cycle was detected in landomycin E-treated cells (16). Landomycin A was found to inhibit the uptake of thymidine into DNA in murine smooth muscle cells and arrest the cells at $\mathrm{G}_{1} / \mathrm{S}$ phase (34). In this study, we showed that CHM only partially retarded tumor cells at $\mathrm{G}_{2} / \mathrm{M}$ phase and did not involve iron (Fig. 2). Therefore, there may not be a general mechanism by which angucycline/angucyclinone antibiotics interfere with the cell cycle. Interestingly, the ROS generation is rapidly triggered by CHM treatment. Similar results were obtained in landomycin E-treated cells (16). These data suggest that there is a distinct mechanism of ROS generation, in contrast to action of DOX. This mode of ROS generation is worthy of further study.

Anthracycline antibiotics, including DOX, rank among the most effective antitumor drugs in clinical use. There are several mechanisms by which their actions affect tumor cells, such as inhibition of mammalian DNA topoisomerase II, generation of free radicals leading to DNA damage and lipid peroxidation and DNA cross linking (35-37). However, its clinical use is hampered by serious problems such as development of resistance in tumor cells and side effects, most notably in the form of chronic cardiomyopathy and congestive heart failure. According to the present results, unique action of CHM includes the characteristics with rapid generation of ROS, and weak arrest of the cell cycle. Moreover, there was no cross resistance to CHM in DOXresistant MCF-7 cells and vinscristine-resistant KB cells. Our recent research showed in sensitive parental MCF-7 cells that drug resistance was not observed after two months of CHM incubation (data not shown). It has been reported that cytotoxic activity of landomycin E was only weakly reduced in P-gp and MRP-1 overexpressed tumor cells (16). These features are valuable to new development of this kind of antibiotics.

In summary, CHM potently inhibits the proliferation of tumor cells through activation of the caspase pathway. Considering its unique action differing from that of DOX, characterization of the binding sites of CHM in tumor cells is also important as it can provide clues required for further drug design to enhance drug efficacy and mitigate side effects.

\section{Acknowledgements}

The study was supported by grants from National Scientific Foundation of China (No. 30672482, 30772284) and Platform for Great Project of Developing New Drugs in China (2009 ZX09301-003).

\section{References}

1. Sasco AJ: Cancer and globalization. Biomed Pharmacother 62: 110-121, 2008.

2. Han BL, Zhou JQ, Sun CH, Wang N and Nemoto K: A novel immunosuppressant, kanglemycin $\mathrm{C}$, its fermentation, isolation, physico-chemical and biological properties. Chin J Antibotic 20: 173-177, 1995.

3. Li JM and Lin ZB: Suppressive effect of CHM on T and Blymphocyte activation. Acta Pharmacol Sin 20: 546-550, 1999.

4. Li JM and Lin ZB: Kanglemycin C vs ciclosporin on immunosuppression in mice. Acta Pharmacol Sin 20: 65-68, 1999.

5. Li JM and Lin ZB: Effect of kanglemycin C on lymphocyte proliferation induced by tetrandecanoylphorbol acetate and ionomycin. Acta Pharmacol Sin 21: 188-192, 2000.

6. Johnstone RW, Ruefli AA and Lowe SW: Apoptosis: a link between cancer genetics and chemotherapy. Cell 108: 153-164, 2002.

7. Okada $\mathrm{H}$ and Mak TW: Pathways of apoptotic and non-apoptotic death in tumor cells. Nat Rev Cancer 4: 592-603, 2004.

8. Datta SR, Brunet A and Greenberg ME: Cellular survival: a play in three Akts. Genes Dev 13: 2905-2927, 1999.

9. Amaravadi R and Thompson CB: The survival kinases Akt and Pim as potential pharmacological targets. J Clin Invest 115: 2618-2624, 2005

10. Wada T and Penninger JM: Mitogen-activated protein kinases in apoptosis regulation. Oncogene 23: 2838-2849, 2004.

11. Xia Z, Dickens M, Raingeaud J, Davis RJ and Greenberg ME: Opposing effects of ERK and JNK-p38 MAP kinases on apoptosis. Science 270: 1326-1331, 1995.

12. Sun CH, Wang Y, Wang Z, Zhou JQ, Jin WZ, You XF, Gao H, Zhao LX, Si SY and Li X: Chemomicin A, a new angucyclinone antibiotic produced by Nocardia mediterranei subsp. kanglensis 1747-64. J Antibiot (Tokyo) 60: 211-215, 2007.

13. Antal N, Fiedler HP, Stackebrandt E, Beil W, Ströch K and Zeeck A: Retymicin, galtamycin B, saquayamycin Z and ribofuranosyllumichrome, novel secondary metabolites from Micromonospora sp. Tü 6368. I. Taxonomy, fermentation, isolation and biological activities. J Antibiot (Tokyo) 58: 95-102, 2005.

14. Schimana J, Fiedler HP, Groth I, Süssmuth R, Beil W, Walker M and Zeeck A: Simocyclinones, novel cytostatic angucyclinone antibiotics produced by Streptomyces antibioticus Tü 6040. I. Taxonomy, fermentation, isolation and biological activities. J Antibiot (Tokyo) 53: 779-787, 2000.

15. Krohn K and Rohr J: Angucyclines: total syntheses, new structure, and biosynthetic studies of an emerging new class of antibiotics. Top Curr Chem 188: 127-195, 1997.

16. Korynevska A, Heffeter P, Matselyukh B, Micksche EM, Stoika R and Berger W: Mechanisms underlying the anticancer activities of the angucycline landomycin E. Biochem Pharmacol 74: 1713-1726, 2007.

17. Kalivendi SV, Konorev EA, Cunningham S, Vanamala SK, Kaji EH, Joseph J and Kalyanaraman B: Doxorubicin activates nuclear factor of activated T-lymphocytes and Fas ligand transcription: role of mitochondrial reactive oxygen species and calcium. Biochem J 389: 527-539, 2005.

18. Sunters A, Madureira PA, Pomeranz KM, et al: Paclitaxelinduced nuclear translocation of FOXO3a in breast cancer cells is mediated by c-Jun NH2-terminal kinase and Akt. Cancer Res 66: 212-220, 2006.

19. Eom YW, Kim MA, Park SS, et al. Two distinct modes of cell death induced by doxorubicin: apoptosis and cell death through mitotic catastrophe accompanied by senescence-like phenotype. Oncogene 24: 4765-4777, 2005.

20. Alexandre J, Hu Y, Lu W, Pelicano H and Huang P: Novel action of paclitaxel against cancer cells: bystander effect mediated by reactive oxygen species. Cancer Res 67: 3512-3517, 2007.

21. Chen YC, Lin-Shiau SY and Lin JK: Involvement of reactive oxygen species and caspase 3 activation in arsenite-induced apoptosis. J Cell Physiol 177: 324-333, 1998.

22. Tsang WP, Chau SP, Kong SK, Fung KP and Kwok TT: Reactive oxygen species mediate doxorubicin induced p53-independent apoptosis. Life Sci 73: 2047-2058, 2003.

23. Biroccio A, Benassi B, Amodei S, Gabellini C, Del Bufalo D and Zupi G: c-Myc down-regulation increases susceptibility to cisplatin through reactive oxygen species-mediated apoptosis in M14 human melanoma cells. Mol Pharmacol 60: 174-182, 2001. 
24. Green PS and Leeuwenburge C: Mitochondrial dysfunction is an early indicator of doxorubicin-induced apoptosis. Biochim Biophys Acta 1588: 94-101, 2002.

25. Clementi ME, Giardina B, Di Stasio E, Mordente A and Misiti F: Doxorubicin-derived metabolites induce release of cytochrome $\mathrm{C}$ and inhibition of respiration on cardiac isolated mitochondria. Anticancer Res 23: 2445-2450, 2003.

26. Rohr J and Thiericke R: Angucycline group antibiotics. Nat Prod Rep 9: 103-137, 1992.

27. Taniguchi M, Nagai K, Watanabe M, Nimura N, Suzuki K and Tanaka A: YM-181741, a novel benz[a]anthraquinone antibiotic with anti-Helicobacter pylori activity from Streptomyces sp. J Antibiot (Tokyo) 55: 30-35, 2002.

28. Grabley S, Hammann P, Hütter K, Kluge H, Thiericke R, Wink J and Zeeck A: Secondary metabolites by chemical screening. Part 19. SM 196 A and B, novel biologically active angucyclinones from Streptomyces sp. J Antibiot (Tokyo) 44: 670-673, 1991.

29. Alvi KA, Baker DD, Stienecker V, Hosken M and Nair BG: Identification of inhibitors of inducible nitric oxide synthase from microbial extracts. J Antibiot (Tokyo) 53: 496-501, 2000.

30. Kawashima A, Kishimura Y, Tamai M and Hanada K: New platelet aggregation inhibitors. Chem Pharm Bull (Tokyo) 37: 3429-3431, 1989

31. Kimura K, Kanou F, Koshino H, Uramoto M and Yoshihama M: SNA-8073-B, a new isotetracenone antibiotic inhibits prolyl endopeptidase. I. Fermentation, isolation and biological properties. J Antibiot (Tokyo) 50: 291-296, 1997.
32. Miyata S, Ohhata N, Murai H, Masui Y, Ezaki M, Takase S, Nishikawa M, Kiyoto S, Okuhara M and Kohsaka M: WS009 A and B, new endothelin receptor antagonists isolated from Streptomyces sp. no. 89009. I. Taxonomy, fermentation, isolation, physico-chemical properties and biological activities. J Antibiot (Tokyo) 45: 1029-1040, 1992

33. Polishchuk LV, Hanusevych II and Matseliukh BP: The antitumor action of antibiotics produced by Streptomyces globisporus 1912 studied in a model of Guerin's carcinoma in rats. Mikrobiol Z 58: 55-58, 1996.

34. Crow RT, Rosenbaum B, Smith R, Guo Y, Ramos KS and Sulikowski GA: Landomycin A inhibits DNA synthesis and G1/S cell cycle progression. Bioorg Med Chem Lett 9: 1663-1666, 1999.

35. Tewey KM, Rowe TC, Yang L, Halligan BD and Liu LF: Adriamycin induced DNA damage mediated by mammalian DNA topoisomerase II. Science 226: 466-468, 1984.

36. Rabbani A and Finn RMJ: Ausio, the anthracycline antibiotics: antitumor drugs that alter chromatin structure. BioEssays 27: 50-56, 2005.

37. Minotti G, Menna P, Salvatorelli E, Cairo G and Gianni L: Anthracyclines: molecular advances and pharmacologic developments in antitumor activity and cardiotoxicity. Pharmacol Rev 56: 185-229, 2004. 